\title{
Teacher Identity and the Neoliberal Condition: Asserting a Participative-Professional, Socially Democratic Teacher Imaginary in Technical-Managerial Times
}

\author{
Lawrence Angus \\ University of Ballarat \\ Email: I.angus@ballarat.edu.au
}

\section{Doi:10.5901/jesr.2013.v3n7p170}

\section{Abstract}

Drawing on extensive ethnographic research in disadvantaged communities, the paper describes the effects of 30 years of neoliberal education policy on the teaching profession. I describe the type of teacher identity that is promoted by neoliberal discourse, and which is doing damage to countless young people, as 'technical-managerial'. Teachers are expected to be effective instructors but educational ideas and democratic values are largely missing from this view of teaching, which is strongly aligned with individual, institutional and national economic competition. I distinguish this restricted perspective from a more engaged, relational type that I describe as 'participative-professional'. Within this latter perspective, teachers would be engaged, critically reflective practitioners - active participants in educational and organizational politics and policy and well as pedagogy. I conclude that teachers must strive to assert participative-professional teacher identities in order to restore notions of social justice to the moral purpose of education.

Keywords: teacher identity, neoliberalism, education policy, social justice.

\section{Introduction}

During the past thirty years there have been major changes in government and public thinking about education. This has occurred in Australia and in most Western countries (Lingard, 2010), and also in many developing nations (Nordtveit, 2010). There has been what Ball $(2006,10)$ and many others regard as 'a major transformation in the organising principles of social provision right across the public sector'. Ball's general point is that the nature of western society as a whole, including its underlying values and organising norms, or what Taylor (2007) would call its 'social imaginary', has substantially changed in less than a generation. In this paper I describe some of the changes that have been asserted in the values and policy directions in education in Australia and elsewhere, and attempt to explain the impact of such changes on the teaching profession. I will argue that the changes, by and large, have had a deleterious effect on teaching and have contributed to the deprofessionalization of teachers to the point that serious debate is needed on what kind of schooling and what kind of teachers are desirable and, indeed, necessary, for the $21^{\text {st }}$ century.

\section{Teaching within an entrenched, neoliberal policy regime}

To raise education standards and drive national economic competitiveness, there has been an enormous emphasis in many countries on so-called 'failing' schools and teachers, and on the presumed need for monitoring and regulating schools and teaching. This thinking has resulted in policies of narrow accountability, market competition among schools, and the use of 'league tables'. This way of framing education through a discourse of blame and standardization is extremely powerful in promoting an educational quasi-market, but is dangerous and damaging to educational values as it decreases teachers' professional autonomy (Ball 2006, 2003). I argue below that the resulting 'standards agenda' displays a managerial approach in which teaching and learning are regarded as technical processes that occur within the 'black box' of the school.

Relatively early in the period of neoliberal ascendancy I argued elsewhere that the type of teacher professionalism that was presumed to be appropriate could best be described as 'technical-managerial' (Angus 1994). I distinguished this from a more engaged, relational approach to teacher professionalism that I described as 'participative-professional'. I use these terms not to construct a binary but in trying to distinguish between broad, different ways of conceptualising teacher identity. My aim at the time was (and still is) to advance a 'social and educational vision of democratic and participative school arrangements [that can contribute] to an equitable and socially just society' (p.30). Characteristics of these 
approaches are highlighted in Figure 1. My argument presumes that different values, principles and ways of 'doing' education are at stake, and my main point is that 'educational' ideas and values are largely missing from the current education policy agenda, which is strongly aligned with the needs of the economy. This linkage has profound implications for ways in which the purposes of education have been asserted.

Figure 1: 'Technical-managerial' and 'participative-professional' ways of seeing professional educational practice (Adapted from Angus 1994, 30)

\begin{tabular}{|c|c|}
\hline Technical-Managerial & Participative-Professional \\
\hline Characterized By & Characterized By \\
\hline $\begin{array}{l}\text { an implementation mentality associated with top-down, } \\
\text { external control and educational conformity to specified } \\
\text { rules and ends. Teachers provide quality instruction }\end{array}$ & $\begin{array}{l}\text { a reformulation mentality associated with internal expertise } \\
\text { and processes, and openness to educational alternatives. } \\
\text { Teachers construct and assert shared good practice }\end{array}$ \\
\hline $\begin{array}{l}\begin{array}{l}\text { bureaucratic-hierarchical roles specified by } \\
\text { managerialist rationality }\end{array} \\
\end{array}$ & $\begin{array}{l}\text { social actors in a specific context in which roles are open, } \\
\text { at least in part, to negotiation and change }\end{array}$ \\
\hline $\begin{array}{l}\text { people at the school level are largely objects of } \\
\text { organizational management-policy which is done to } \\
\text { them sometime in the guise of so-called 'best practice' }\end{array}$ & $\begin{array}{l}\text { people at the school level are largely subjects who } \\
\text { participate in the creation-utilization-adaptation of } \\
\text { organizational policy and good practice }\end{array}$ \\
\hline $\begin{array}{l}\text { technical rationality prevails with an emphasis on } \\
\text { delivery of mandated requirements and top-down } \\
\text { accountability for professional performance and } \\
\text { expertise }\end{array}$ & $\begin{array}{l}\text { social-educational concerns and issues prevail with an } \\
\text { emphasis on being answerable to educational, social and } \\
\text { community needs and to professional, educational values }\end{array}$ \\
\hline $\begin{array}{l}\text { school level participants take problems as defined by } \\
\text { policy- hierarchy: problems and solutions are identified } \\
\text { in school effectiveness and-or managerial discourses to } \\
\text { which 'best practice' and the incorporation of school } \\
\text { effectiveness factors should apply }\end{array}$ & $\begin{array}{l}\text { school level participants make problems as identified } \\
\text { through the 'good practice' of local participants: issues are } \\
\text { identified in relation to the local context and within a broad } \\
\text { understanding of the relationship between educational and } \\
\text { social responsibilities }\end{array}$ \\
\hline $\begin{array}{l}\text { emphasis is on efficiency and effectiveness: achieving } \\
\text { pre-specified results and targets }\end{array}$ & $\begin{array}{l}\text { emphasis is on worthwhileness: achieving educational and } \\
\text { social gains that are empowering to local participants }\end{array}$ \\
\hline $\begin{array}{l}\text { performativity: students as 'clients' and emphasis on } \\
\text { narrowly defined student and teacher performance as } \\
\text { specified in a top-down manner }\end{array}$ & $\begin{array}{l}\text { engagement: students as 'members' and co-learners with } \\
\text { teachers and others who strive to be relevant to and } \\
\text { respectful of local contexts }\end{array}$ \\
\hline $\begin{array}{c}\text { Results In } \\
\Downarrow\end{array}$ & $\begin{array}{c}\text { Results In } \\
\Downarrow\end{array}$ \\
\hline $\begin{array}{l}\text { linear outcomes-predicted results- rep } \\
\text { status quo- deprofessionalization }\end{array}$ & $\begin{array}{l}\text { uncertain effects-diverse consequences- possibility of } \\
\text { reform and change- professional responsibility }\end{array}$ \\
\hline
\end{tabular}

An important distinction can be made between the two broad conceptualizations outlined in figure 1 in terms of their relationship to social context. In technical-managerial approaches, context is largely a backdrop or a source of inputs to which the school responds by taking appropriate managerial action. Close monitoring and accountability measures ensure that schools 'do the right thing' in terms of imposed policies and mandates which are expected to be implemented largely unquestioningly. That is, the approach allows for very little, if any, real discretion at the local level. The emphasis is on the end-product - the achievement of performance indicators and the implementation of mandated policies such that prescribed results are achieved and targets are met. In a participative-professional approach, in contrast, the definition of problems and solutions within a school is likely to be a very different, more complex matter. Educational problems and priorities would be seen in relation to the dynamic interplay between education and society - as matters that need to be addressed contextually and collaboratively rather than by managerial, technical means. In a participativeprofessional conceptualization, the school is regarded as a site of social, political and cultural interaction. Educational processes and policy are not seen as neutral, and participants are regarded as social and political actors who make a difference rather than simply as occupants of organizational roles. That is, the participative-professional orientation requires an activist perspective on the part of teacher-professionals who are capable of pursuing 'transformative agendas' that 'challenge the status quo and contribute to a more egalitarian social order' (Lather 1986, 64).

Such thinking presents a direct contrast to technical-rational 'policy implementation', which tends to assume that schools conform to a natural, 'real' social order which has a neutral, underlying value consensus (Bowe, Ball and Gold 1992). By treating conventional educational arrangements as if they occur naturally, this approach reifies existing social and political conditions which are treated as if they must necessarily be the way they are. Such presumed neutrality and 
objectivity of technical-rational approach to education implicitly endorses the status quo. It assumes neutrality and 'common sense' within a paradigm of accountability, compliance and 'performativity' (Ball 2003). The neoliberal framework, with its market arrangements and heavy compliance regimes under which schools have increasingly had to operate over the past 30 years, have tended to push and shove teachers towards an impersonal attitude towards students and communities. According to Thomson, Hall and Jones $(2010,652)$, this quantitative approach has inhibited more humane, richer, authentic and socially responsible forms of teaching and erodes educational creativity and imagination through the

$$
\begin{aligned}
& \text {... equation of organizations, teachers and pupils into categories and numbers, where schooling is seen as infinitely } \\
& \text { calculable and available for calibration and permanently available for forensic dissection through apparently objective, } \\
& \text { scientific and transparent computational practices. }
\end{aligned}
$$

Such technical-managerial mechanisms translate students and their experiences into 'hard data' but, as these authors remind us:

good data [is] not the same as good education if that is taken to mean students being productively engaged in learning which is worthwhile and gives access to powerful concepts which have explanatory power in the world (p.653).

In contrast to technical-managerialism, participative-professional approaches attempt to deal with schools and communities as social sites in which wider social relations are played out and mediated through the everyday lived experiences and perceptions of the human agents involved. Such thinking helps teachers and education leaders perceive the connections between their personal, micro-political lives and the larger macro forces that bear down upon them and influence society and education. They may develop a critical spirit of inquiry and reflection which would aim towards emancipatory and democratic goals. Such teachers would have a critical concern with reflecting on how they can accommodate, resist, and interrupt prevailing discourses. My point is that, by adopting a spirit of inquiry, critique and interrogation in their everyday practice, teachers can become better able to reflect on their work and to question, analyse and understand their own educational locales and the state of education more broadly. An immediate priority for such interrogation is the current economic framing of education, in which schools, principals, teachers and, most importantly, students, in keeping with a technical-managerial perspective, are treated as objects of policy to whom schooling is 'done'.

\title{
3. Asserting and contesting subject positions in education
}

McGraw $(2011,105)$ explains that, instead of schools acknowledging the skills and competence of students, and opening up new and empowering 'possibilities of being and knowing', many young people experience the 'worst' aspects of schooling. She states:
At its worst, [school] narrows opportunities and creates formidable whirlpools of anxiety, fear and distrust. Schools 'sort' and 'shove' young people in ways that are both physical and imagined... This institutional preference for dividing and selecting, for noting and disregarding, leads to poor attendance at school, resistance, disengagement and early school leaving.

However, it is not only students, but also teachers, who are terribly constrained within the current climate. As McGraw points out:

\begin{abstract}
Teachers too are struggling to maintain their own professional and personal identities in a profession that is increasingly moving beyond their control. . . Teachers, like young people are shoved forcefully to the side and pressured to conform to the political, social and economic agendas of the day. They too are left feeling disoriented, disarmed and disengaged. Amidst such pressure, opportunities for open dialogue are minimized and relationships suffer $(2011,110)$.
\end{abstract}

This last point is critical. The thinking behind policies of narrow accountability, competition, and the use of 'league tables' to rank schools against each other, assumes the culpability of individual students, schools and teachers rather than social, cultural and economic issue that contribute to educational injustice. Pushed into the background are the issues and problems of everyday life that must be dealt with inside and outside classrooms by educators and young people. The accountability regime defines what is 'officially' important, but the multiple forms and causes of educational disadvantage that exist in and around schools have become largely irrelevant to considerations of educational reform. Local knowledge, locally generated curriculum, and shared, good teaching and learning practice tend to be disregarded. 
Hence the need for teachers to ...

learn how to look at the world from multiple perspectives, including those of students whose experiences are quite different from their own, and to use this knowledge in developing pedagogy so they can reach diverse learners (DarlingHammond 2000, 170).

To exercise such a critical disposition, and to see beyond one's own perspective, teachers need to confront any deficit orientations of their own towards working-class children and their communities. It is important to transform such views into an 'assets-based' orientation that acknowledges and respects alternative knowledge bases and curriculum resources that can be drawn upon from within minority and working-class communities and cultures (Cummins, 2001; Moll et al., 1992). By incorporating such assets into their teaching, teachers would be engaging in advocacy education while they were learning and teaching collaboratively with their students. According to Cummins $(2001,653)$, this would 'start by acknowledging the cultural, linguistic, imaginative and intellectual resources poor children bring to school'. Such a collaborative approach to pedagogy requires a socially-informed, qualitative understanding of the social context of schools and of the lives and experiences of students - an approach that is vastly different from the managerial and measurement orientation of the technical-managerial, neoliberal framework. The participative-professional approach obviously offers a much richer notion of what being a teacher entails. As Cochran-Smith and Lytle (2004) explain:

Teaching goes far beyond what teachers do when they stand in front of students, just as student learning is not limited to the classroom ... It is about how teachers and their students construct the curriculum, commingling their experiences, their cultural and linguistic resources, and their interpretive frameworks. Teaching also entails how teachers' actions are infused with complex and multilayered understandings of learners, culture, class, gender, literacies, social issues, institutions, 'herstories' and histories, communities, materials, texts, and curricula.

Moll and his colleagues argue that this kind of socially critical and culturally relevant teaching takes account of the 'historically accumulated and culturally developed bodies of knowledge and skills [within communities] essential for household or individual functioning and well-being' (Moll et al. 1992, 132). These authors are determined 'to develop innovations in teaching that draw upon the knowledge and skills found in local households' (p.132). By drawing on the concept of 'funds of knowledge', they argue that, 'by capitalizing on household and other community resources, we can organize classroom instruction that far exceeds in quality the rote-like instructions these children commonly encounter in schools' (p.132). Instead, the teacher ...

will know the child as a 'whole person', not merely as a 'student', taking into account or having knowledge about the multiple tiers of activity within which the child is enmeshed. In comparison, the typical teacher-student relationship seems 'thin' and 'single-stranded', as the teacher 'knows' the students only from their performance within rather limited classroom contexts (Moll et al. 1992, 133-4).

The important task for the teaching profession is to develop the radical potential of this concept of 'funds of knowledge' so teachers can ensure that their classrooms will not be sealed off from the 'social worlds and resources of the community' (Moll et al. 1992, 134) which exist beyond the walls of the school. According to Moll and colleagues, the pedagogical situation can then become one in which 'learning is motivated by the children's interests and questions; in contrast to [conventional] classrooms, knowledge is obtained by the children, not imposed by the adults' (p.134). In short, teachers would attempt to uncover the different ways of seeing and knowing practiced by students and their families. The school community would be viewed as a source of 'cultural and cognitive resources with great, potential utility for classroom instruction' (p.134). This view, the authors point out:

contrasts sharply with prevailing and accepted perceptions of working-class families as somehow disorganized socially and deficient intellectually; perceptions that are well accepted and rarely challenged in the field of education and elsewhere (Moll et al. 1992, 134).

The important point here is that teachers would come to assert, and celebrate in their work, the essential human agency, creativity and obduracy of educators, community members and students at all levels who continue to work within the constraints of social structures, embedded power relations and professional cultures to create a space for challenge of the obstacles to achieving social justice in education. There is no avoiding the conclusion that education is a political and ideological arena in which teachers are important players. Most importantly, it is critical that teachers become alert to both micro and macro political influences on the nature of their work. Educators must learn to become participative- 
professional teacher activists who will have sufficient confidence to assert their professionalism despite the climate of top-down managerial control and the powerful effects on the public consciousness of the neoliberal discourse of markets, testing, accountability, standards and the like.

\title{
4. Addressing the declining professional autonomy of educators
}

The decline in the professional autonomy of teachers over the past three decades must be reversed. According to Ball (2003), the technical-managerial concept of 'performativity' has resulted in strategies of surveillance (such as publishing test scores and ranking schools) that consolidate a culture of coercion and compliance within the education profession. Teachers have become caught up in the 'politics of blame' as 'high-stakes' testing has imposed a powerful constraint on their work. The effect is that conceptions of what constitutes a 'good' teacher have become distorted, as have long-held and previously-accepted beliefs about the social and democratic purposes of schooling. The situation, as described by Fitzgerald $(2008,126)$, has reached the point where teachers have been 'removed from public debate and are now required to deliver organizational objectives; objectives that are linked with the demands of the global marketplace and economic capital'. Carr and Hartnett $(1996,195)$ regard this situation as a direct attack on teacher professionalism:

\begin{abstract}
[T]he professionalism of teachers is based on the recognition of their right to make autonomous judgments about how, in particular institutional and classroom contexts, to develop their students' capacity for democratic deliberation, critical judgment and rational understanding. Without this kind of professional autonomy, teachers have no protection against external coercion and pressure, and they quickly become neutral operatives implementing the 'directives' of their political masters and mistresses.
\end{abstract}

Within such a climate of mistrust, teachers' subject positions have been challenged. Being a member of a profession implies the ability to assert what Bourdieu might call its professional culture or, more precisely in his terms, to define the professional field of teaching in terms of its distinctive cultural and symbolic capital. Members of the teaching professional field, then, should be willing to define, assert and defend a body of norms and knowledge that, although never entirely stable, gives them grounds for claiming internal and external legitimacy. Thus, although contested, members need to keep asserting the importance of their broad professional knowledge and judgement because, if they do not, the nature and status of the profession will become more problematic as 'the cultural capital of the [professional] field is lost' (Oakes et al., 1998, 263).

Like Fitzgerald and the others quoted above, I would argue that the teacher professional field has been attacked and shaped in subtle and not-so-subtle technical-managerial ways during the past 30 years. The importance of market competition among schools, for example, has become universally recognized as a pragmatic imperative for schools. This is a strong illustration of the material effects of performativity that Ball (2003) has emphasized. The cultural capital of the professional field has been problematized and the characteristics that were once associated with 'good teaching' (e.g. curriculum expertise, teaching and learning innovation, a social justice orientation, making the curriculum relevant in local contexts) have been devalued. In Bourdieu's terms, previously asserted versions of professional capital have been contested and reconstructed.

Mechanisms of market, managerialism and accountability have amounted to transformative technologies in the implementation of educational change as well as being outcomes of change in themselves. They have had 'systemchanging' effects (McDonell \& Elmore 1987). As the discourses that link managerialism and standards have become regularized into organizational thinking and practices in schools, they have had a profound effect on conceptions of education and the education profession. The overall effect is that long-established beliefs and understandings about the purposes of schooling have been distorted in this process. The effect is that:

\section{Schooling has mutated from a way of preparing young people for broader purposes (such as participation in democratic society) to a mechanism of selection and preparation for the local and global labour market. In other words, the unquestioned purpose and responsibility of schools is [now] to provide the workforce necessary to compete in the global economy (Fitzgerald, 2008, 124).}

The upshot is that technical-managerial, market-oriented, neoliberal norms and assumptions have been asserted within a supposedly value-neutral education policy discourse. The professionalism of teachers has been restricted and the technical-managerial orientation reflects a conservative and backward-looking conception of the appropriate relationships between schools and communities. An alternative educational future requires a form of teacher professionalism that, in both conceptual and practical terms, is far more relational and participative. Within the current 
educational discourse, accountability has taken on the status of a political ideology that embraces policies that build into a relatively solid neoliberal framework of management, surveillance and control. The ideology of accountability has grown increasingly powerful. Nonetheless, alternative 'educational' values, such as equity, responsiveness, critique, studentcentred learning, and concern with the social context of schooling, would become more dominant within a policy discourse that was education-led or 'pedagogy-led'.

A focus on instruction and test-taking has largely come to define 'twenty-first century learning'. This is consistent with a technical-managerial approach. It is consistent with the 'corporatization (or marketization, or economization) of the 21st century learner, his/her desired skills, dispositions and capabilities' (Williams et al 2013, 2):

Thus, the goal of schooling becomes the production of the ideal neoliberal subject. This is most evident in the specification of the '21st century learner' as the self-managing, entrepreneurial individual, lifelong learner and responsibilized citizen of the post-welfare state.

Such neoliberal thinking ignores the point that the major influences on the school performance of young people exist outside rather than inside the school (Angus 2012). We need to think about how education, as a social institution, systematically advantages and/or disadvantages certain types of people in certain types of communities. All students deserve to be treated in a more dignified, engaged and respectful manner than occurs within the ideology of technicalmanagerialism. Activist, participative-professional teachers need to reach out to all young people, particularly disadvantaged young people, and move to meet them rather than expect them to adjust to entrenched school and teacher paradigms that reflect the norms of unacknowledged privilege. Schools can then be successful in engaging all students in relevant and interesting school experiences.

\section{Teachers of the future: Critical, reflective and relational}

The taken-for-granted norms and assumptions embedded in the neoliberal policy framework are important not only because of their anti-educational effects on education, but also because they displace and marginalize alternative, more humanistic conceptions of education that are associated with participative-professional approaches. For teachers to be critical, reflective and activist practitioners, they must resist the hegemonic effects of the neoliberal policy regime. Educators are operating in environments in which the emphasis on outcomes and policy compliance is the order of the day. Webb $(2005,204)$ claims that 'increased accountability pressure [has] created conditions where participants became additional agents of the external accountability system, not self-governing agents of their own expectations'. If Webb is correct, teachers have lost their professional-participative disposition and succumbed to technicalmanagerialism.

No doubt many teachers have taken on board, at least to some extent, pragmatic compliance with policy mandates and have become wary of rocking the boat. But numerous critical, reflective practitioners do consider the social outcomes of education and promote democratic opportunities for learning. They need to advocate and promote a social justice orientation that embraces inclusive teaching and learning. Teachers need to develop a relational perspective on education in order to see schools as important sites in which social processes and education politics are played out. Fundamental to developing a sense of democratic, emancipatory possibilities within the teaching profession is the realization that schools, like other social institutions, contribute to the construction and legitimation of advantage and disadvantage, and to the broader cultural production and legitimation of societal norms. The legitimation of the values implicit in neoliberal discourse has made it difficult for alternative discourses to be 'heard', but, as Bowe and his colleagues (1992) emphasize, any discourse is open to continuous amendment and reinterpretation, especially at the school level. From a teacher's perspective, there is always some capacity for school-level re-interpretation and adaptation of education policy as alternative professional judgments and educational practices are asserted by professional-participative teachers. The kind of democratic social responsibility and commitment to social justice that might be expected from critically reflective, professionally-informed teachers, then, would be reflected in attempts to make schools inclusive of all learners, even the most problematic ones.

\section{Conclusion: Working with a socially democratic professional imaginary}

The fact that education is a social institution that has not managed to achieve its historic democratic and egalitarian objectives does not mean we should give up trying. But if schools are to be successful in their democratic mission, teachers must be encouraged to experiment with various definitions of desirable future selves working in the best 
interests of all young people, their families and the future society they envisage. In short, as Rizvi and Lingard (2010) have convincingly argued, teachers need to develop an alternative 'social imaginary' to that foreshadowed by neoliberal education policy.

This concept of 'social imaginary' is explained by Taylor $(2007,119)$ :

\begin{abstract}
What I am trying to get at with this term is something much broader and deeper than the intellectual schemes people may entertain when they think about social reality in a disengaged mode. I am thinking rather of the ways in which they imagine their social existence - how they fit together with others and how things go on between them and their fellows, the expectations that are normally met and the deeper normative notions and images that underlie these expectations.
\end{abstract}

The most powerful and dominant social imaginary in the current historical period, according to Rizvi and Lingard (2010), is 'the neoliberal imaginary' The task for activist, critically-informed education professionals is to problematize and 'reimagine' the neoliberal imaginary, and to replace it with a more educationally appropriate and socially just alternative - a 'socially democratic imaginary'. Within such an imagined state of education, professional-participative teachers would exercise autonomy and discretion in critically appraising and re-interpreting mandated policy in the social and democratic interests of their students, communities and the common good. In keeping with such a socially democratic imaginary, and consistent with participative-professional notions of teaching, teachers would contribute to education debates and work with fellow teachers, students, administrators and school communities to develop practices of critical scrutiny. Such an approach would be consistent with teachers seeing their role as not merely conveying knowledge for consumption but also 'helping students to become creative, critical thinkers and active social participants, and to become capable of redefining the nature of their own lives in the society in which they live' (Gordon, 1985).

Hursh and Henderson $(2011,182)$ point out that, at present:

\begin{abstract}
Schools are more often places where teachers and students learn what will be on the test rather than seeking answers to questions that cry out for answers, such as how to develop a healthy, sustainable environment or communities where people are actually valued for who they are rather than what they contribute to the economy.
\end{abstract}

The aim of this paper has been to critically consider the need for teachers who are willing and able to critically reflect on themselves, their practices, their experiences in classrooms and schools, and the current education system and imagined alternatives. I have proposed a participative-professional, socially democratic teacher imaginary that should be regarded as much more than a simple ideal. It is a way of conceptualising the kind of teachers and schools that are needed for the future. Teachers can imagine themselves into the reality of becoming active, informed agents who have a social responsibility to re-connect the nexus between schooling and democratic engagement, and to shape themselves and their schools into the kind of educators and educational institutions that will enable all young people and their communities to contribute as citizens, workers and participating members in their preferred future.

\title{
References
}

Angus, L. (2012). Teaching within and against the circle of privilege: Reforming teachers, reforming schools. Journal of Education Policy, 27(2), 231-251

Angus, L. (1994). Educational organization: technical-managerial and participative- professional perspectives. Discourse: Studies in the Cultural Politics of Education, 14(2), 30-44.

Ball, S. (2006). Education policy and social class. London: Routledge.

Ball, S. (2003). The teacher's soul and the terrors of performativity. Journal of Education Policy, 18(2), 215-228.

Bowe, R., Ball, S. \& Gold, A. (1992). Reforming education and changing schools. London: Falmer Press.

Carr, W. \& Hartnett, A. (1996). Education and the struggle for democracy. Buckingham, UK: Open University Press.

Cochran-Smith, M. \& Lytle, S. (2004). Practitioner inquiry, knowledge, and university culture. In J. Loughran, M.L. Hamilton, V. LaBoskey \& T. Russell (Ed.), International handbook of research of self-study of teaching and teacher education practices (602649). Dordrecht: Kluwer.

Cummins, J. (2001). Empowering minority students: A framework for introduction (classic reprint). Harvard Education Review, 71(4), 649-675.

Darling-Hammond, L. (2000). How teacher education matters. Journal of Teacher Education, 51(3), 166-173.

Fitzgerald, T. (2008). The continuing politics of mistrust: performance management and the erosion of professional work. Journal of Educational Administration and History, 40(2), 113-128.

Gordon, L. (1985). Towards emancipation in citizenship education: the case of Afro-American cultural knowledge. Theory and Research in Social Education, 12(4), 1-23.

Hursh, D. \& Henderson, J. (2011). Contesting global neoliberalism and creating alternative futures. Discourse: Studies in the Cultural 
Politics of Education, 32(2), 172-185.

Lather, P. (1986). Research as praxis. Harvard Educational Review, 56(3), 257-277.

Lingard, B. (2010). Policy borrowing, policy learning: testing times in Australian schooling. Critical Studies in Education, 51(2), $129-147$.

McDonnell, M, \& Elmore, R. (1987). Getting the job done: alternative policy instruments. Educational Evaluation and Policy Analysis, $9(2), 133-152$.

McGraw, A. (2011). Shoving our way into young people's lives. Teacher Development, 15(1), 105-116.

Moll, L., Amanti, C., Neff, D. \& Gonzalez, N. (1992). Funds of knowledge for teaching: using a qualitative approach to connect schools and classrooms. Theory into Practice, 31(2), 132-141.

Nordtveit, B. (2010). Towards post-globalisation? on the hegemony of western education and development discourses. Globalisation, Societies and Education, 8(3), 321-337.

Oakes, L., Townley, B. \& Cooper, D.J. (1998). Business planning as pedagogy: language and control in a changing educational field. Administrative Science Quarterly, 48(2), 257-292.

Rizvi, F. \& Lingard, B. (2010). Globalizing education policy. New York: Routledge.

Taylor, C. (2007). Cultures of democracy and citizen efficacy. Public Culture, 19(1), 117-150.

Thomson, P., Hall, C. \& Jones, K. (2010). Maggie's day: a small-scale analysis of English education policy. Journal of Education Policy, 25(5), 639-656.

Webb, P. (2005). The anatomy of accountability. Journal of Education Policy, 20(2), 189-208.

Williams, C., Gannon, S. \& Sawyer, W. (2013): A genealogy of the 'future': antipodean trajectories and travels of the '21st century learner', Journal of Education Policy, DOI:10.1080-02680939.2013.776117 